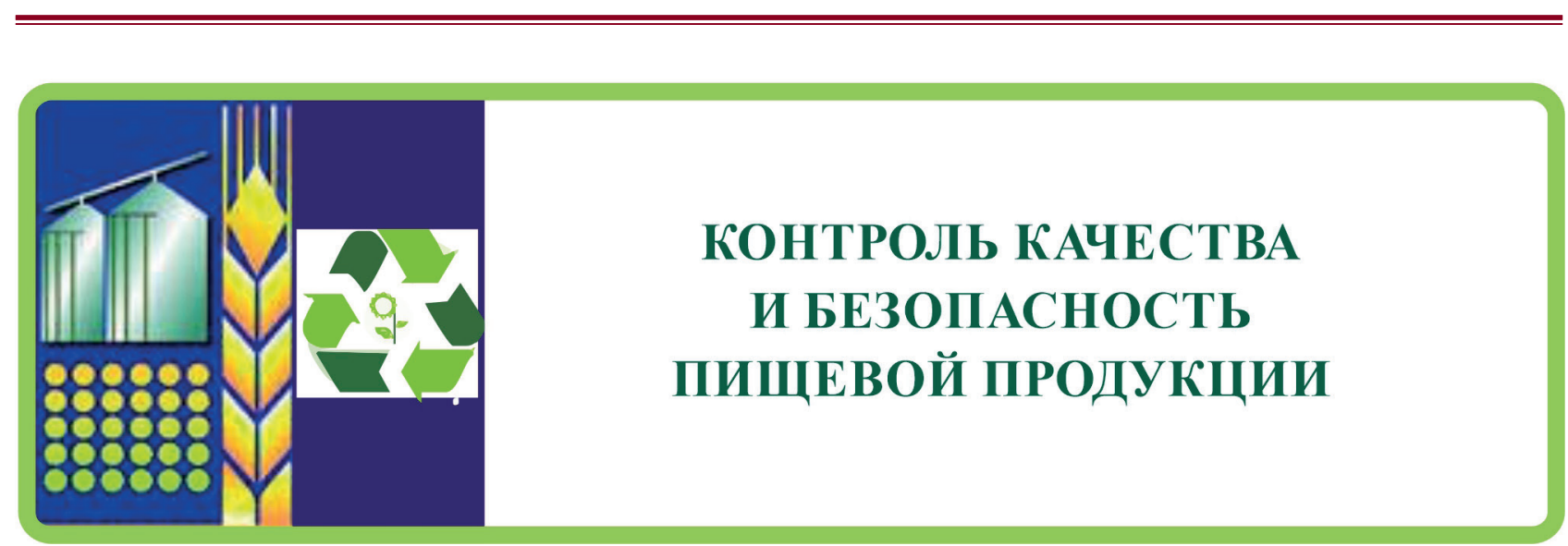

УДК 338.43.02

DOI:10.31677/2072-6724-2021-33-3-5-13

\title{
АНАЛИЗ ПРОДОВОЛЬСТВЕННОЙ БЕЗОПАСНОСТИ ЧЕЛЯБИНСКОЙ ОБЛАСТИ
}

\author{
В.С. Зыбалов, доктор сельскохозяйственных наук, доцент \\ Н.Л. Наумова, магистрант \\ Южно-Уральский государственный университет (НИУ) \\ E-mail: n.naumova@inbox.ru
}

Ключевые слова: продовольственная безопасность, сельскохозяйственная продукция, агропромышленный комплекс, самообеспечение.

Реферат. Решение задач, направленных на достижение гарантированного уровня обеспеченности населения продовольствием, неразрывно связано с созданием условий для конкурентоспособного развития сельского хозяйства, которое во многом определяет уровень экономической безопасности и соииальной стабильности страны. В последние годы Челябинская область входит в десятку лучших регионов Российской Федераџии по производству продовольствия. Однако агропромышленный комплекс области имеет ряд слабых сторон, в частности низкую самообеспеченность молоком и продуктами его переработки. Целью исследования явилось изучение продовольственной безопасности Челябинской области по отдельным показателям, таким как динамика промышленного производства основных групп пищевой продукии; уровни самообеспечения Челябинской области хлебо-, мясо- и молокопродуктами; сырьевые ресурсы перерабатывающих предприятий. Определено, что Челябинская область имеет мощный промышленный потенциал. Региональное сельское хозяйство играет ведушую роль в формировании продовольственной безопасности. Своевременные инвестиции в развитие сырьевой и производственной базы предприятий мясной и мукомольно-крупяной отраслей позволили достичь высоких показателей в промышленном производстве мяса птицы, свинины, хлебобулочных, крупяных и макаронных изделий. Рацион питания южноуральиев сбалансирован по хлебу и мясным продуктам, но по молочным товарам несколько отстает от рекомендованной нормы. Причиной последнего являются слабая сырьевая база (сокращение численности дойного стада), высокие затраты на производство сырья и низкая инвестиционная привлекательность молочного животноводства.

Решение задач, направленных на достижение гарантированного уровня обеспеченности населения продовольствием, неразрывно связано с созданием условий для конкурентоспособного развития сельского хозяйства, которое во многом определяет уровень экономической безопасности и социальной стабильности страны. В последние годы Челябинская область входит в десятку лучших регионов Российской Федерации по производству продовольствия 
[1-4]. Производство сельскохозяйственной продукции и основных видов продукции пищевой и перерабатывающей промышленности в области показало рост в первом полугодии 2020 г., несмотря на пандемию коронавируса. В 2020 г. предприятия работали в новых условиях, связанных с пандемией, которые вынудили компании пересмотреть объемы, логистику, направления поставок. Но агрокомплекс справился с современными вызовами и сохранил объемы производства, выполнив все параметры продовольственной безопасности, обеспечивая бесперебойные поставки продуктов питания на местный рынок и за пределы региона. Так, уровень самообеспеченности региона мясом всех видов составил более 200 \%, куриным яйцом - 174, картофелем и овощами - 147,3, хлебными продуктами (в том числе мукой и крупами) - 306,4, молоком и молочными продуктами $-56,3 \%[5,6]$.

По итогам работы в первом полугодии 2020 г. по сравнению с аналогичным периодом 2019 г. в Челябинской области объем производства продукции в хозяйствах всех категорий составил 40,6 млн руб. (40,1 млн в первом полугодии 2019 г.). В частности, было произведено на 5,6 \% больше продукции переработки из говядины, свинины, баранины, на 3,4 \% выросло производство колбасных изделий, на 7 - муки и макаронных изделий, на $59 \%$ - растительных масел. Производство овощей в зимних теплицах составило 13,5 тыс. т (+13,4 \%), молока в сельскохозяйственных организациях - 89 тыс. т (+6,1\%), яиц на птицефабриках - 770,6 млн шт. (+2,9 \%). Среди регионов Российской Федерации по итогам 2020 г. Челябинская область заняла 4-е место по производству яиц, 8-е -по производству скота и птицы на убой в живой массе и 19-е место по объему продукции сельского хозяйства $[5,6]$. Однако агропромышленный комплекс Челябинской области имеет и ряд слабых сторон, в частности низкую самообеспеченность молоком и продуктами его переработки.

Целью исследования явилось изучение продовольственной безопасности Челябинской области по отдельным показателям.

В качестве объекта исследований выступила информационная база, а именно сведения, содержащиеся в официальных источниках, целевые индикаторы Доктрины продовольственной безопасности РФ [7] и Государственной программы развития сельского хозяйства и регулирования рынков сельскохозяйственной продукции, сырья и продовольствия на 2013-2020 годы [8]. В работе использованы методы группировки и сравнительного анализа.

Развитие пищевых производств имеет большую социальную значимость. Рассматривая вопрос об уровне обеспеченности населения Челябинской области социально значимыми продуктами питания, необходимо отметить, что в последние годы предприятия пищевой промышленности работали достаточно стабильно. Детальное изучение развития промышленного производства отдельных продуктов питания потребительской корзины представлено на рис. 1.

За 2013-2019 гг. региональное производство мясопродуктов претерпело существенные изменения. Объемы производства продукции снизились на 36,8 \% - с 394,2 до 249,0 тыс. т. Среднегодовой темп снижения составил 4,6 \%. Однако в этот же период отмечена положительная динамика в развитии производства молокопродуктов - объемы выпуска увеличились на $30,3 \%$, среднегодовой темп роста составил 3,8 \%. Хлебопекарная промышленность на протяжении четырех лет, с 2013 по 2016 г., переживала некоторые колебания, но уже в 2017 г. был достигнут уровень производства хлебобулочных изделий, свойственный для предприятий отрасли в предыдущие годы. Затем наблюдалось увеличение объемов производства хлебобулочных изделий до 250,0 тыс. т, при этом темп роста составил 33,3 \% [9, 10].

Проблема производства продуктов питания, составляющих основу обеспечения потребления населения, является актуальной. В связи с этим особое значение приобретает сбалансированное соотношение между их производством и потреблением. На основе оценки сбалансированности осуществляется ввоз продуктов питания при неудовлетворенном спросе и вывоз - при их производстве сверх спроса. На базе балансов продовольственных ресурсов опре- 


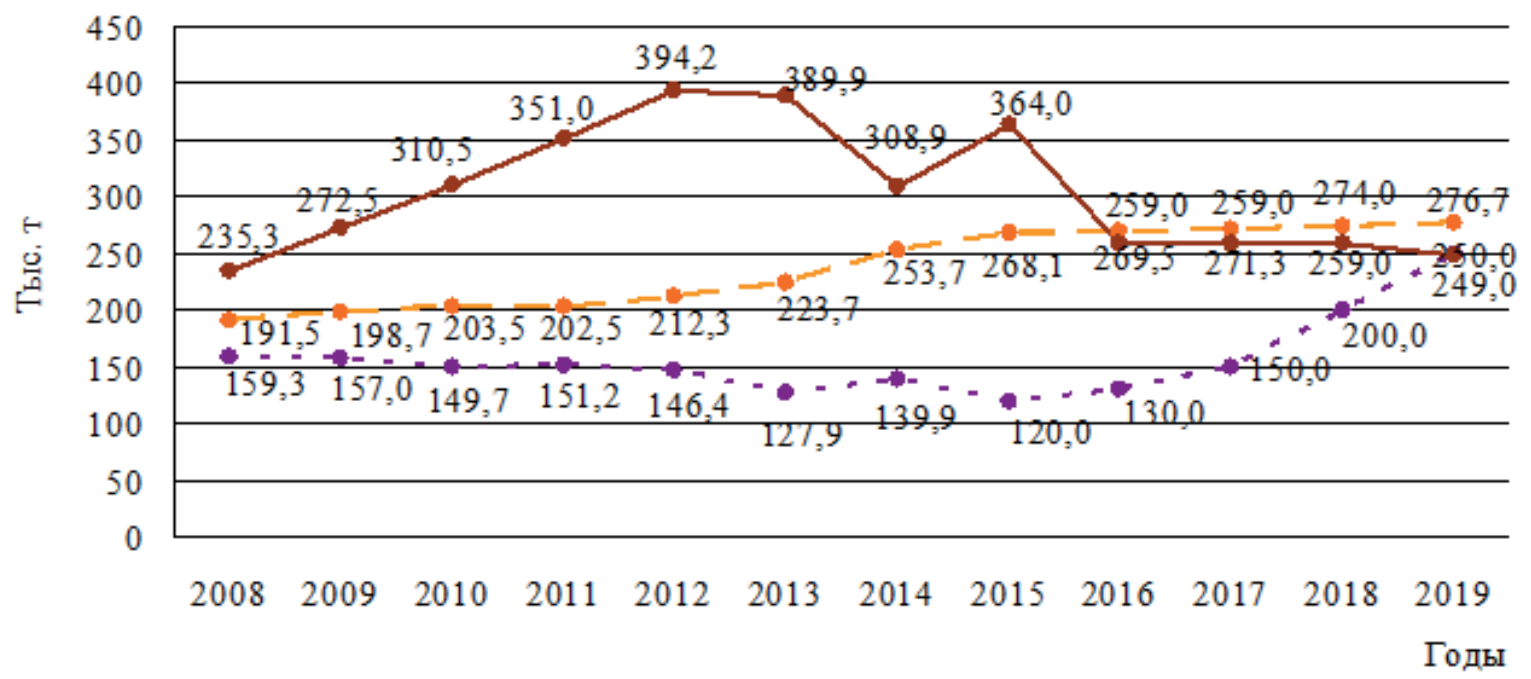

- - хлебобулочные изделия - молочная продукция - мясопродукты

Puc. 1. Сравнительная динамика объемов производства продуктов предприятиями Челябинской области деляется показатель, характеризующий продовольственную безопасность региона, - уровень самообеспечения основными видами сельскохозяйственной продукции.

За анализируемый двенадцатилетний период снижение объемов производства хлебопродуктов в целом (хлеба, хлебобулочных и макаронных изделий, круп, муки) на душу населения пришлось на 2014-2017 гг. и составило 10,4-12,5 \%, объемов потребления - 23,1% (рис. 2). Уровень потребления хлебопродуктов южноуральцами в 2019 г. максимально приблизился к рекомендуемой норме (96 кг). Учитывая, что объемы потребления хлебопродуктов на протяжении многих лет более чем в 2 раза превышали объемы их производства, становится очевидным низкий уровень самообеспечения местного населения лишь отдельными хлебопродуктами, поскольку из других источников известно [5], что уровень самообеспечения хлебом и хлебобулочными изделиями в 2019 г. составил $301,2 \%$.

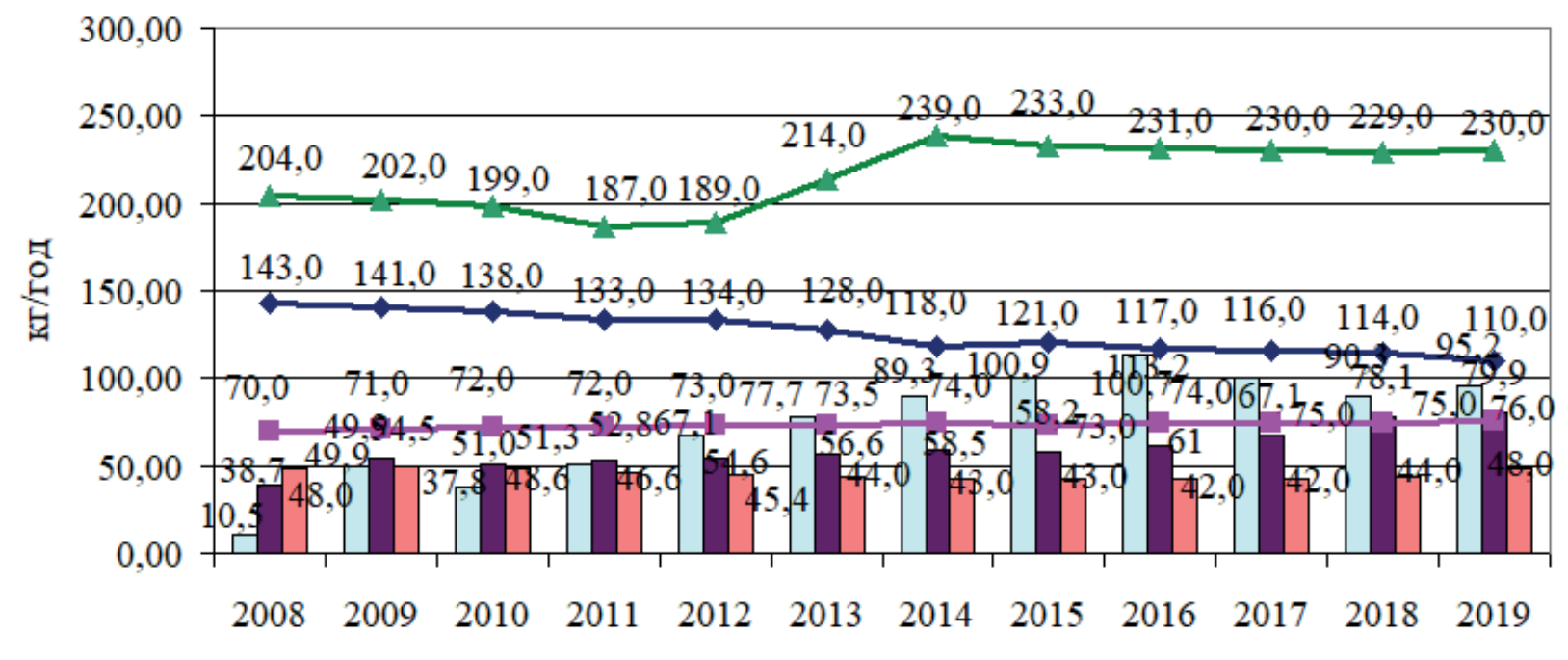

Годы
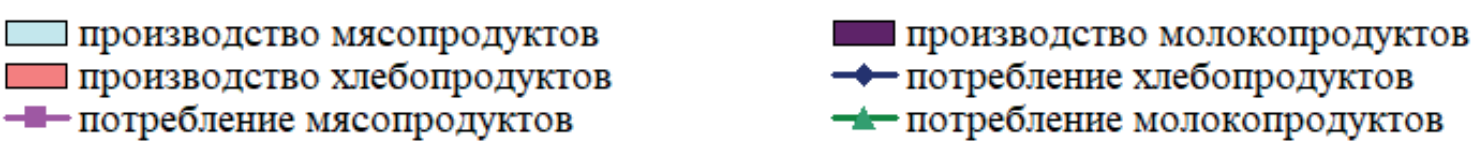

Puc. 2. Промышленное производство и потребление продуктов на душу населения 
Детально изучив данный вопрос, мы получили следующие результаты. Челябинская область является одним из ведущих регионов - производителей муки и круп в стране. Здесь выпускают порядка 8 \% от общероссийского объема муки и около 11 \% круп. Кроме того, 25 \% рынка макаронных изделий в России принадлежит Челябинской области. В некоторых сегментах, например в производстве круп в варочных пакетах, челябинские производители занимают до $50 \%$ российского рынка [11]. В 2019 г. в Челябинской области произведено 664,5 тыс. т муки - это второе место в России после Алтайского края, где выпущено 1083,8 тыс. т муки. Однако с 2017 г. в регионе наметилась тенденция к снижению объемов производства муки. В частности, в 2019 г. по сравнению с 2018 г. снижение составило 0,2 \%. Среди основных факторов, формирующих данный тренд, - высокая конкуренция в отрасли из-за наличия в регионе большого количества крупных и малых мукомольных предприятий. Из бюджета Челябинской области в 2019 г. впервые было выделено 60 млн руб. на покрытие части расходов предприятий-экспортеров по перевозке продукции автомобильным транспортом до пунктов пропуска через государственную границу. В результате экспорт муки из региона за 2019 г. составил 7,0 тыс. т на сумму 2,6 млн долл., тогда как в 2018 г. - 4,4 тыс. т на сумму 1,4 млн долл., т.е. рост в натуральном выражении составил $59 \%$.

Параллельно постепенно уменьшается использование муки на производство хлеба, хлебобулочных и макаронных изделий по причине того, что показатель самообеспеченности жителей региона хлебобулочными изделиями уже достиг 301,2 \% в 2019 г. (355,433 кг в год на человека вместо реально потребляемых 116 кг). Постепенно снижается и потребление муки домохозяйствами в свете современной тенденции к ведению здорового образа жизни, предполагающего в том числе снижение потребления мучных изделий. Кроме того, значительные объемы муки завозятся в Челябинскую область из соседних регионов (Курганская, Оренбургская области) по более низким ценам. Так, по состоянию на 20 февраля оптовая цена пшеничной муки, согласно данным ведомственного мониторинга Минсельхоза России, в Челябинске составила 21,18 руб/кг, в Кургане - 18,35, в Оренбурге - 19,0 руб/кг.

В 2019 г. производство круп предприятиями пищевой промышленности региона повысилось на 4,7 \% и составило 174,3 тыс. т. Это третье место в России следом за Алтайским (433,9 тыс. т) и Краснодарским (387,5 тыс. т) краями [11]. Рост производства круп во многом связан с региональной инвестиционной политикой. К примеру, власти Челябинской области в 2018 г. поддержали инвестиционный проект одного из основных в регионе производителей круп (ООО «Ресурс», торговая марка «Увелка») по строительству производственно-логистического комплекса с объемом инвестиций 3,4 млрд руб. После реализации проекта переработка гречихи в компании увеличилась в 3,7 раза (до 6,5 тыс. т в месяц), овса, ячменя, пшеницы и гороха - в 4,5 раза (до 10,7 тыс. т), хлопьев - в 2,7 раза (до 8,5 тыс. т), крупы в варочных пакетах и мягкой упаковке - в 1,7 раза (до 20,2 тыс. т).

Известно, что по молоку и молочным продуктам продовольственная безопасность России не обеспечена, их потребление не соответствует рациональным нормам. Самообеспеченность России молочными продуктами остается ниже целевого уровня начиная с 1994 г., при этом минимум был достигнут в 2013 г. [12].

По объемам потребления молокопродуктов ситуация в Челябинской области складывается значительно хуже. Объемы производства молочных продуктов на душу населения за период 2008-2019 гг. увеличились в 2 раза, а объемы их потребления - на 12,7 \% [9, 10]. Согласно приказу Министерства здравоохранения РФ от 19.08.2016 № 6141, рациональная норма потребления молочных продуктов на душу населения составляет 325 кг. Фактическое же потребление на жителя Челябинской области в 2019 г. составило 230,0 кг, что ниже рекомендуемой нормы на 29,2 \%. К тому же объемы производства молока и молокопродуктов оказались ниже объемов их потребления в 2,9 раза, что свидетельствует о низком уровне самообеспечения Челябинской 
области молочной продукцией. В Доктрине продовольственной безопасности РФ определены пороговые значения производства молока и молокопродуктов (в пересчете на молоко) - не менее 90 \% от общего потребления. В Челябинской области на сегодняшний день этот показатель не выполняется.

Ряд специалистов называют молочную индустрию, наряду с мясной, самой уязвимой отраслью российского сельского хозяйства, так как молочный рынок в наибольшей мере зависит от импорта и показывает максимальный рост цен среди сельскохозяйственных рынков.

Потребление мясопродуктов в период 2008-2019 гг. населением Челябинской области возросло. К 2019 г. этот показатель увеличился с 70 до 76 кг, что стало соответствовать рекомендуемой норме потребления (73 кг на душу населения). Начиная с 2013 г. объемы производства мяса и мясопродуктов на душу населения стали превышать объемы их потребления, что свидетельствует о высоком уровне самообеспечения продукцией мясного животноводства [5].

Зерно и продукты его переработки чрезвычайно важны в решении проблемы обеспечения продовольственной безопасности Челябинской области. Они относятся к продовольствию стратегического назначения, пригодны к длительному хранению в качестве резервных фондов. Динамика объемов производства зерна и использования зерновых ресурсов в исследуемый период характеризовалась нестабильностью (рис. 3), что объясняется зависимостью отрасли от погодных условий.

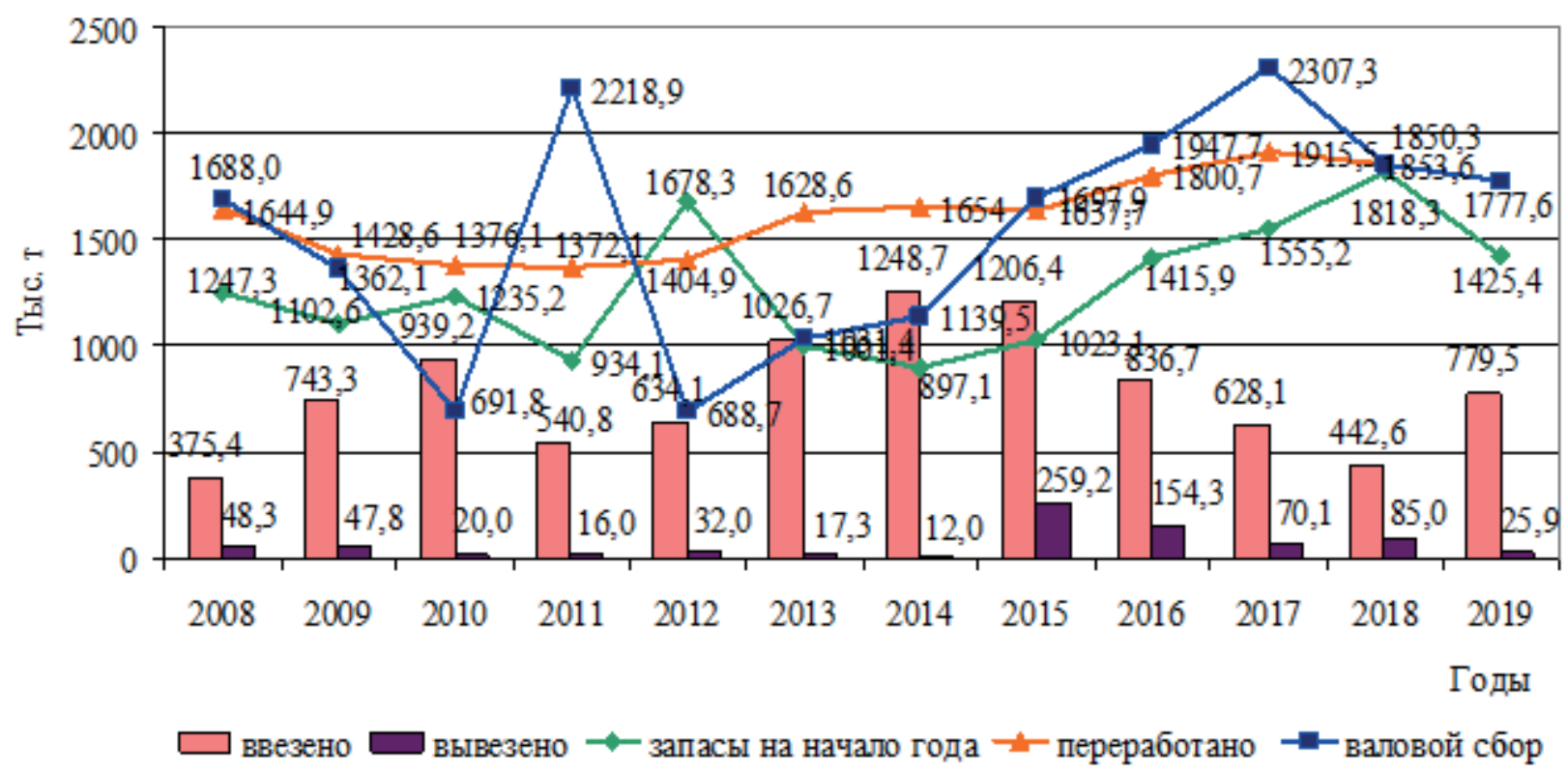

Puc. 3. Баланс ресурсов и использования зерна в Челябинской области

Так, в 2010 г. значительное снижение (на 52,4 \% по отношению к показателю 2009 г.) объемов производства зерна и увеличение доли (на 26,4 \%) ввезенного сырья объясняется засушливым летом. Следующий, 2011 г. выдался урожайным, и индекс производства зерна в хозяйствах сельхозтоваропроизводителей области составил 320,7 \% по отношению к 2010 г. В 2012 г. по сравнению с 2011 г. зерновые ресурсы уменьшились на 18,8 \%, что связано с уменьшением объемов производства зерна в отчетный период, также обусловленным засушливым летом. По этой же причине снизился уровень самообеспечения области зерном с 111,0 \% в 2011 г. до 35,0 \% в 2012 г., но ситуацию удалось спасти за счет значительных запасов (1678,3 тыс. т) зерновой массы урожая 2011 г. При относительно благоприятных климатических условиях, зафиксированных в 2011 и 2017 гг, уровень самообеспечения области зерном был достаточно высок. 
Агрофирма «Ариант» запустила в 2016 г. первую очередь нового элеватора в пос. Красногорский мощностью 190 тыс. т единовременного хранения зерна. Завершение строительства второй очереди обеспечило хранение 290 тыс. т зерна единовременно. В строительстве и оснащении объекта использованы самые современные технологии и оборудование [13].

В анализируемый период доля ввезенного в область зерна в общем объеме зерновых ресурсов существенно колебалась - от 375,4 тыс. т в 2008 г. до 1248,7 тыс. т в 2014 г. Объемы вывоза зерна за пределы Челябинской области в это время были незначительны - от 12,0 тыс. т в 2014 г. до 259,2 тыс. т в 2015 г.

Удельный вес крестьянских (фермерских) хозяйств, включая индивидуальных предпринимателей, в общем объеме производства зерна в 2020 г. составил 51,0 \% (в 2019 г. - 49,9 \%), сельскохозяйственных организаций - 43,5 \% (в 2019 г. - 44,8 \%). Валовой сбор зерна в 2020 г. составил 1008,1 тыс. т в массе после доработки), что на 43,3 \% меньше уровня предыдущего года. Причина снижения - возникновение чрезвычайной ситуации природного характера, связанной с почвенной и атмосферной засухой, в 20 муниципальных образованиях Челябинской области.

В отличие от растениеводства, процесс производства в животноводстве непрерывен, продукция производится круглый год, ее выход меньше зависит от климатических условий и в большей мере - от кормовой базы, вложений труда, условий специализации производства и т.д.

По состоянию на 2018 г. из почти 400 тыс. т сырого молока, которое поступало на молокозаводы области для переработки, только 60 \% было произведено южноуральскими животноводами, остальное сырье закупалось в соседних регионах. При этом годовое потребление готовых молочных продуктов, по данным Росстата, составляло на Южном Урале около 645 тыс. т. Анализ статистических данных показывает, что в объемах производства молока в хозяйствах всех категорий области с 2008 по 2019 г. отмечался постепенный спад, который к настоящему времени достиг 33 \% (рис. 4). Ситуация объяснима сокращением численности дойных коров за этот период на 72,9 тыс. голов $(38,1 \%)$. В 2019 г. в области ресурсы молока составили 748,7 тыс. т, что на 0,4 \% меньше, чем в 2018 г. Из имеющихся ресурсов 685,3 тыс. т (91,5 \%) было использовано для производства молочных продуктов $[9,10]$.

Объемы ввоза и вывоза молочного сырья с территории области претерпели определенные изменения. Так, уровень ввоза сырого молока для переработки повысился в 9,3 вывоза - в 1,7 раза. Одним из способов стимулирования производства сырого молока является увеличение закупочной цены. Главными причинами, тормозящими развитие молочного рынка, являются слабая сырьевая база и высокие затраты на производство сырья [12]. Несмотря на это, в хозяйстве «Подовинное» запущен новый доильный зал фирмы «Делаваль», закуплено 500 нетелей в Ленинградской и Свердловской областях, в СПК «Коелгинское» началось строительство молочной фермы (коровник беспривязного содержания на 400 голов), ОАО «Совхоз Акбашевский» проектирует молочный комплекс на 400 голов коров [13].

Надои молока на одну корову в сельскохозяйственных организациях в 2019 г. составили 5606 кг против 5673 кг в 2018 г., в 2020 г. - 6097 кг, что на 8,8 \% больше, чем в 2019 г. Аналитический центр Milknews провел исследование молочного рынка страны за первые восемь месяцев 2020 г. и выяснил, что с января по август больше всего молочной продукции было произведено в Краснодарском крае, Татарстане и Красноярском крае. Челябинская область оказалась на 17-м месте в этом списке. В регионе было произведено чуть больше 80 тыс. т молока, что на 5,2 \% больше, чем в прошлом году.

Региональные власти успешно решили проблему обеспечения населения мясом и мясопродуктами. Отправной точкой развития сельскохозяйственной отрасли стала реализация с 2006 г. национального проекта «Развитие АПК». Наиболее интенсивно развивалась отрасль птицеводства. В 2006 г. в строительство, реконструкцию и модернизацию объектов птицеводства 


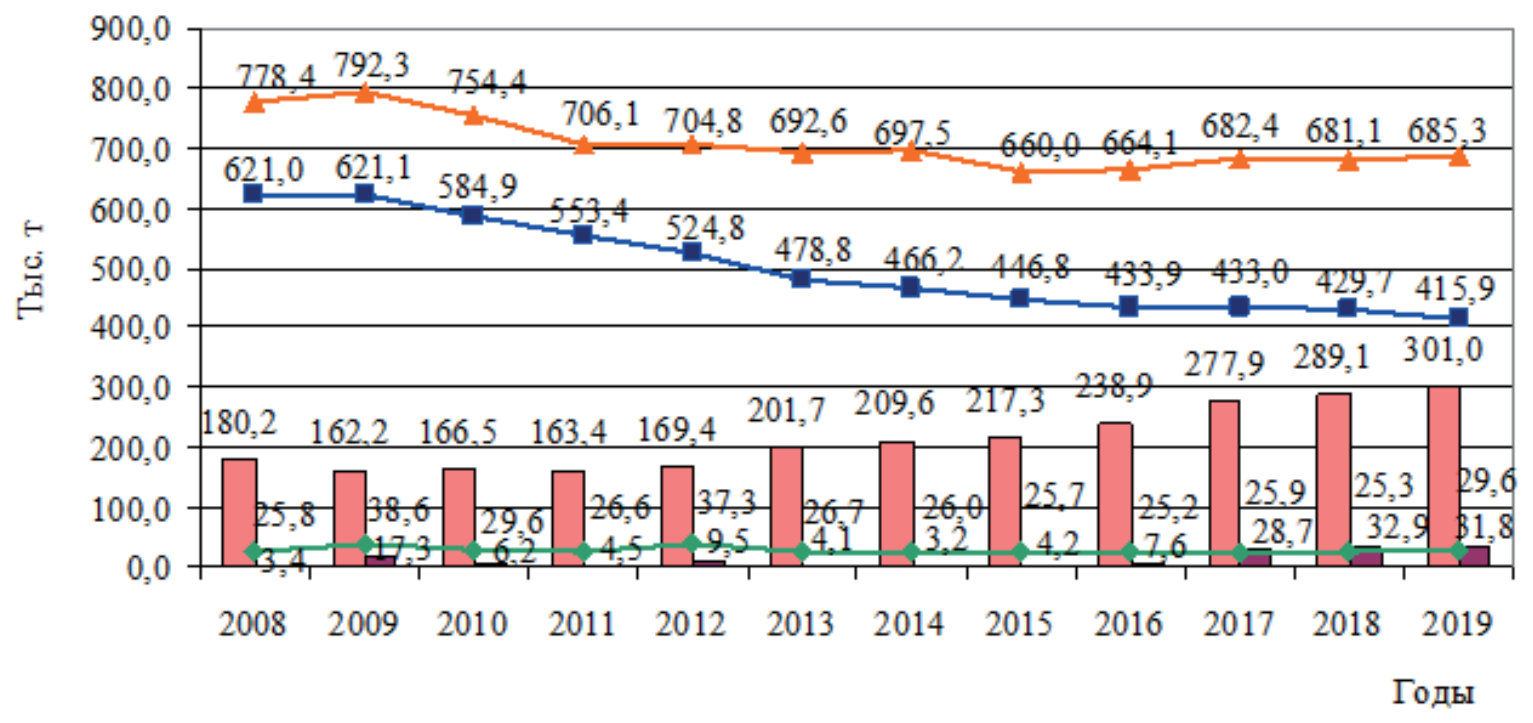

вв езено $\square$ вывезено $-\bullet$ запасы на начало года

произведено

$\rightarrow$-переработано

Puc. 4. Баланс ресурсов и использования молочного сырья в Челябинской области

в области было направлено свыше 20 млрд руб. Одновременно совершенствовалась инфраструктура производства, строились новые комбикормовые заводы, убойные цеха, инкубаторы, появлялись торговые дома и сети розничной торговли. Самую высокую динамику в мясной отрасли сегодня демонстрирует свиноводство. В увеличение производственных мощностей Родниковского свинокомплекса с объемом производства 18 тыс. т свинины в год было вложено 4,5 млрд руб. В 2015 г. в Троицком районе МПК «Ромкор» запустил новый свиноводческий комплекс (производственная мощность объекта 7,8 тыс. т мяса в живой массе в год), агрофирма «Ариант» вложила в увеличение производственных мощностей более 11 млрд руб. (мощность предприятия - 92 тыс. т). Помимо производственных объектов для содержания и разведения свиней, построена фабрика мясной гастрономии с современным убойным цехом и мясоперерабатывающим комбинатом ежедневной производительностью до 140 т продукции [13]. В результате объемы производства мяса с 2008 по 2019 г. увеличились в 2 раза (рис. 5), существенно повысилась (в 11,2 раза) доля вывезенного мясного сырья за пределы области и снизились объемы (на 16,4 \%) ввоза мяса в Челябинскую область.

В 2016 г. производство мяса птицы за месяц в среднем составило 29 тыс. т. Для примера, наивысший годовой показатель советского периода составлял 28,0 тыс. т, а в перспективных планах стояла цифра 50 тыс. т. В 2016 г. на всех свинокомплексах произведено 115 тыс. т мяса, что на $41 \%$ больше показателя 2015 г.

На конец декабря 2019 г. поголовье крупного рогатого скота в хозяйствах всех сельхозпроизводителей составляло 228,6 тыс. голов (на 4,7 \% меньше по сравнению с данными на конец ноября 2018 г.), в том числе коров - 114,8 тыс. голов (на 2,9 \% меньше), свиней - 876,3 тыс. голов (на 2,5 \% больше), овец и коз - 144,9 тыс. голов (на 3,8 \% меньше), птицы - 25925,9 тыс. голов (на $8,2 \%$ больше). В структуре поголовья скота на хозяйства населения приходилось 43,9 \% поголовья крупного рогатого скота, 50,3 - коров, 5,2 - свиней, 87,1 - овец и коз (на конец декабря 2018 г. - соответственно 44,8; 51,4; 5,8 и 86,2 \%). В 2019 г. в хозяйствах всех категорий произведено скота и птицы на убой (в живой массе) 530,6 тыс. т (97,9 \% к 2018 г.), молока - 415,9 тыс. т $(96,8 \%)[9,10]$.

В 2019 г. в структуре производства скота и птицы на убой (в живой массе) в сельскохозяйственных организациях отмечалось увеличение удельного веса производства птицы по сравнению с уровнем 2018 г. В 2020 г. производство скота и птицы на убой в хозяйствах всех кате- 


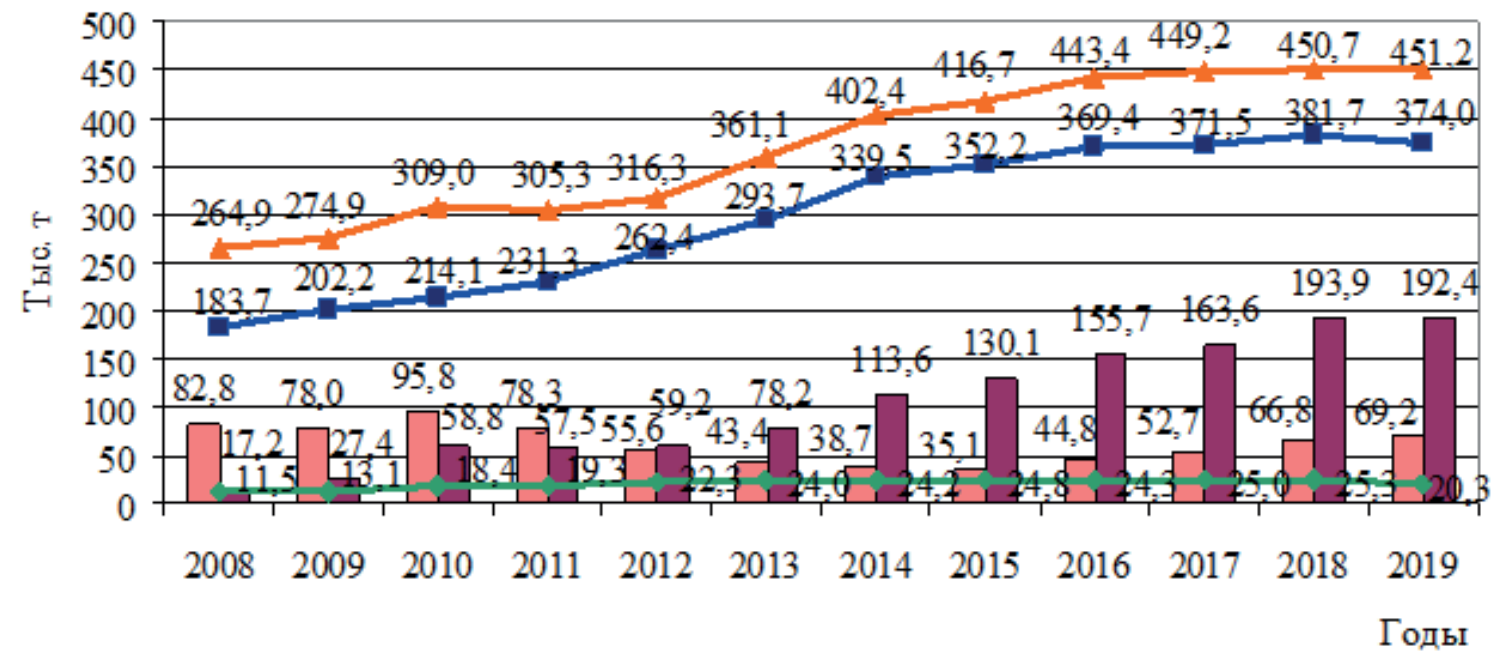

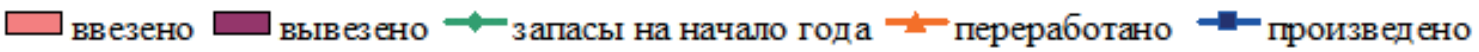

Puc. 5. Баланс ресурсов и использования молочного сырья в Челябинской области

горий (в живой массе) составило 493,3 тыс. т (92,9 \% к 2019 г.), молока - 415,0 тыс. т (99,8 \%). Снижение объема производства произошло в птицеводстве, что обусловлено сложной эпизоотической обстановкой в подотрасли и экономической ситуацией в период пандемии (снижение покупательского спроса, рост цен на корма и энергоносители).

Оценивая в целом продовольственную безопасность Челябинской области, можно отметить следующее.

1. Челябинская область имеет мощный промышленный потенциал. Региональное сельское хозяйство играет ведущую роль в формировании продовольственной безопасности страны.

2. Своевременные инвестиции в развитие сырьевой и производственной базы предприятий мясной и мукомольно-крупяной отраслей позволили достичь высоких показателей в промышленном производстве мяса птицы, свинины, хлебобулочных, крупяных и макаронных изделий.

3. Рацион питания среднестатистического южноуральца сбалансирован по хлебу и мясным изделиям, но по молочным продуктам несколько отстает от рекомендованной нормы.

4. Реализация региональных программ развития сельского хозяйства и целенаправленная государственная поддержка, в том числе субсидирование отдельных мероприятий и прямые финансовые вложения в развитие молочного животноводства, будут способствовать повышению производительности, рентабельности и расширению ассортимента высококачественной молочной продукции местного производства.

\section{БИБЛИОГРАФИЧЕСКИЙ СПИСОК}

1. Новикова И.А. Точки роста конкурентоспособности Челябинской области: стратегические приоритеты в сельском хозяйстве // Вестник Южно-Уральского профессионального института. - 2015. - № 2 (17). - С. 142-150.

2. Печериева О.Н. Анализ конкурентоспособности регионального АПК // АПК России. 2016. - Т. 23, № 3. - С. 710-713.

3. Маслаков В.В., Курдюмов А.В. Особенности производства агропродукции в АПК Челябинской области // Теория и практика мировой науки. - 2016. - № 2. - С. 41-47.

4. Курдюмов A.B. Агропарк как элемент системы продовольственной безопасности (на примере Челябинской области) // Агропродовольственная политика России. - 2016. - № 9 (60). C. 30-33. 
5. Лукиных М.И. Потребление продуктов питания в Челябинской области // Агропродовольственная политика России. - 2021. - № 1-2. - С. 26-30.

6. Челябинская область в цифрах: Краткий статистический сборник / Челябинскстат. Челябинск, 2021. - 243 с.

7. Доктрина продовольственной безопасности РФ: Указ Президента РФ от 30.01.2010 № 120 // Собрание законодательства РФ. - 2010. - № 5. - С. 502.

8. О Государственной программе развития сельского хозяйства и регулирования рынков сельскохозяйственной продукции, сырья и продовольствия на 2013-2020 годы (с изменениями и дополнениями) [Электронный ресурс]: Постановление Правительства РФ от 14.07.2012 № 717 // Консультант плюс. - Режим доступа: http://www.consultant.ru.

9. Челябинская область в цифрах: Краткий статистический сборник / Челябинскстат. Челябинск, 2016. - 221 с.

10. Статистический ежегодник по Челябинской области: Статистический сборник / Челябинскстат. - Челябинск, 2019. - 435 с.

11. Регионы России. Основные характеристики субъектов Российской Федерации 2019: Статистический сборник / Росстат. - М., 2019. - 766 с.

12. Шинкарёва O.B., Майорова E.A. Оценка потребности России в производстве молока и молочных продуктов для обеспечения рациональных норм личного потребления // Азимут научных исследований: экономика и управление. - 2020. - Т. 9, № 1 (30). - С. 395-397.

13. Раевский A.A. Инвестиционные проекты в агропромышленном комплексе Челябинской области // АПК России. - 2017. - Т. 24, № 1. - С. 9-13.

\section{REFERENCES}

1. Novikova I.A., Vestnik Yuzhno-Ural'skogo professional'nogo instituta, 2015, No. 2 (17), pp. 142- 150. (In Russ.)

2. Pecherceva O.N., APK Rossii, 2016, Vol. 23, No. 3, pp. 710- 713. (In Russ.)

3. Maslakov V.V., Kurdyumov A.V., Teoriya i praktika mirovoj nauki, 2016, No. 2, pp. 41- 47. (In Russ.)

4. Kurdyumov A.V., Agroprodovol'stvennaya politika Rossii, 2016, No. 9 (60), pp. 30- 33. (In Russ.)

5. Lukinyh M.I., Agroprodovol'stvennaya politika Rossii, 2021, No. 1-2, pp. 26-30. (In Russ.)

6. Chelyabinskaya oblast'v cifrah: Kratkij statisticheskij sbornik(Chelyabinsk region in numbers: a brief statistical book), Chelyabinskstat: Chelyabinsk, 2021, 243 p. (In Russ.)

7. Doktrina prodovol'stvennoj bezopasnosti RF: Ukaz Prezidenta RF ot 30.01.2010 g. N 120 (Food security doctrine of the Russian Federation: Decree of the President of the Russian Federation of January 30, 2010 N 120). Collected Legislation of the Russian Federation, 01.02.2010, N 5, art. 502. (In Russ.)

8. http://www.consultant.ru. (In Russ.)

9. Chelyabinskaya oblast'v cifrah: Kratkij statisticheskij sbornik(Chelyabinsk region in numbers: a brief statistical book), Chelyabinskstat: Chelyabinsk, 2016, 221 p. (In Russ.)

10. Statisticheskij ezhegodnik po CHelyabinskoj oblasti: Statisticheskij sbornik (Statistical yearbook for the Chelyabinsk region: statistical collection), Chelyabinskstat: Chelyabinsk, 2019, 435 p. (In Russ.)

11. https://chelagro.ru. (In Russ.)

12. Shinkareva O.V., Mayorova E.A., Azimut nauchnyh issledovanij: ekonomika i upravlenie, 2020, Vol. 9, No. 1 (30), pp. 395- 397. (In Russ.)

13. Raevskij A.A., APK Rossii, 2017, Vol. 24, No. 1, pp. 9- 13. (In Russ.) 